\title{
The Impact of Environmental Performance and Financing Decisions to Sustainable Financial Development
}

\author{
Kenny Ardillah* \\ Matana University \\ Tangerang, Indonesia \\ *kenny.ardillah@matanauniversity.ac.id
}

\begin{abstract}
Companies in achieving sustainability status need to establish a sustainability strategy known as a tradeoff strategy because it can identify the relationship between the results obtained from improvement of environmental performance and financial performance. This research samples focus on mining companies listed on the Indonesia Stock Exchange in the 20152018 period. The research data collection technique is documentation sourced from secondary data derived from annual reports. The data of this research were analyzed using multiple regression analysis. The results obtained in this research are that environmental performance has a positive effect on sustainable financial development, external financing decisions through short-term debt has positive relationship to sustainable financial development and external financing decisions through long-term debt has positive relationship towards sustainable financial development.
\end{abstract}

Keywords-environmental performance, external financing decisions, internal financing decisions, sustainable financial development

\section{INTRODUCTION}

Sustainability becomes an important issue because it integrates financial and non-financial aspects in decision making [1]. Sustainability is defined as a concept that includes environmental, social and economic dimensions. Sustainable development reflects the performance of economic entities can be measured using a sustainable value approach [2]. The sustainable value approach is built on the premise that companies need economic and environmental resources to create economic returns [3].

Companies in achieving sustainability status need to establish a sustainability strategy known as a tradeoff strategy because it can identify the relationship between the results obtained from improved environmental performance and financial performance. The aim of this strategy is to support the creation of environmental values in developing economic value. This is based on the rampant case of green business that has not created economic value through environmental management with the use of economic capital efficiently but by ignoring tradeoffs which in turn makes the company identify and develop environmental strategies to help increase capital returns that are tailored to the risk of the company in creating value economics especially shareholder value [4].
Industry is one of the pillars driving strategic economic growth, but on the other hand operations conducted by companies can have a negative impact on environmental quality. Companies need to increase understanding of environmental aspects through industrial management that is more aware of the importance of environmental performance. One of the programs implemented by KLHK to encourage industry compliance with environmental regulations is the Company Performance Assessment Program in Environmental Management, known as PROPER.

One example of companies that pay attention to environmental performance is PT Bukit Asam Tbk. PT Bukit Asam Tbk won the PROPER with the Gold category in 2020 which made the mining company succeeded in winning the Gold PROPER 7 times in a row since 2013. Throughout 2019, PT Bukit Asam Tbk made various efforts to empower communities and the environment around the company's operational areas that carried out sustainably and consistently so as to provide added value to the community and the environment. Various superior empowerment programs that have been carried out consistently by the company, including Eco-Edu Zoo Park and Kampung Batik Kujur Eco-Friendly at UPTE and Educational Ship Tegal Island in Peltar.

The measure of success in sustainable development is not solely based on growth in financial performance, but also through efforts by companies to improve environmental performance through appropriate and creative financing decisions. As a form of government efforts to participate in environmental protection by striving for public-private collaboration platforms such as TLFF financing facilities that can help translate the government's commitment to achieve SDGs. TLFF has launched a Sustainable Bond with a total of US \$ 95 million that has been disbursed to finance rubber plantations in a sustainable manner on degraded land in Jambi and East Kalimantan Provinces. The planted area will function as a buffer zone to protect national parks that are threatened by encroachment. Around 45,000 of 88,000 hectares will be reserved for the livelihoods of local communities and are expected to open 16,000 jobs.

Indonesia has a wealth of resources and mineral reserves, as well as large coal. The control of resources and reserves in the mining sector is still relatively controlled by national and foreign private companies. Related to the needs of mining company expansion, the company requires substantial funds. 
However, the volatile commodity price movements have made the banking sector very careful in giving credit to mining companies. For example, in 2018 total loans extended by banks to mining companies decreased by $16.06 \%$ on an annual basis. This makes financing decisions an important decision that needs to be made by company management in optimizing the use of the best financing methods that can be sourced from debt or equity to maximize company performance [5].

Financing decisions are important for companies because of the need to maximize returns on sources of financing they use based on the company's ability to deal with its competitive environment. The most important key for companies to choose a portfolio of capital structure that will maintain sustainability and generate more wealth. In general, companies can choose various alternative capital structures such as issuing large or very small amounts of debt. In addition, companies can also use financing based on rental options, use warrants, issue convertible bonds, sign forward contracts or trade exchange bonds [6].

There were some differences in research results in support of the influence of environmental performance on financial performance. Some research results had positive influence of environmental performance on financial performance that was measured by ROA [1,7-10]. There was the result of research related to the positive influence of environmental performance on financial performance that was measured by ROE [7]. In addition, there was one research result that stated the effect of positive influence of environmental performance on financial performance which was measured by Tobin's Q [8].

Researches in determining the effect of financing decisions on financial performance also shows difference results. There were research results that proved the structure of debt had no effect on financial performance [5,11]. Different research results proved that there was a significant and negative relationship of capital structure through short-term liabilities to financial performance, significant and negative relationship of capital structure through long-term liabilities to financial performance, and significant and negative relationship of capital structure through total liabilities to financial performance [12]. In addition, there was research results that proved external financing decisions have a significant and negative effect on financial performance, external financing decisions through short-term debt had a significant and positive effect on financial performance, external financing decisions through long-term debt had a significant and negative effect on financial performance, and internal financing decisions had a significant and positive effect on financial performance [10].

The purpose of this research is to empirically prove the influence of environmental performance, external financing decisions, external financing decisions through short-term debt, external financing decisions through long-term debt, and internal financing decisions on sustainable financial development. This research has a difference with previous research, namely this research focuses on the use of economic performance for the long term in supporting economic aspects of sustainability that are influenced by environmental performance and financing decisions which divided into internal and external financing decisions, research samples focused on mining companies listed on the Indonesia Stock Exchange which is committed to environmental protection and improvement, and a more recent research period with research period of four years from 2015-2018.

\section{LITERATURE REVIEW AND HYPOTHESIS DEVELOPMENT}

\section{A. Pecking Order Theory}

Companies finance their activities with retained earnings if the company's return is sufficient. If the return of earnings is not sufficient for the company, the company uses debt. The pecking order theory showed that companies first prefer internal financial sources and that companies tend to adjust the target payout ratio of returns to shareholders in the form of dividends with investment opportunities. If the company seeks external financial funding, then the company will choose debt as the safest source of funding, hybrid securities such as convertible bonds, and then equity as a last resort. The pecking order theory generally explained why companies rationally allow cash flow to determine the composition of funding through debt. This show that the company will divert funding in the form of debt if the company suffers from under-pressures of internal funds [13].

\section{B. Legitimacy Theory}

The legitimacy theory was defined as a condition when an entity provides support to social groups where the social groups are located. Companies are encouraged to gain legitimacy from the community because they want to ensure that the company's operations are in accordance with norms and boundaries. Legitimacy will be obtained by the company if there are comparable results between the company's performance and the results obtained by the community, so that it will reduce the company's external risk caused by the community itself $[14,15]$. Companies can gain legitimacy from the community by carrying out environmental protection activities and supporting the government's commitment in implementing environmental responsibility through PROPER.

\section{Sustainable Financial Development}

The concept of sustainable development focuses more on the macroeconomic level with two emphases. The first emphasis is on increasing or achieving stabilization of per capita well-being over time without making per capita wellbeing in present or future generations worse. The second is the use of a capital theory approach to sustainability consisting of capital made by humans (such as goods produced), intellectual capital (such as knowledge and skills), natural capital (such as natural resources), and social capital (the relationship between individuals and institution) [16]. In addition to focusing on how fast the company can continue to grow without external financing through debt, the company maintains a growth rate without requiring additional equity. Managers usually determine the optimal capital structure for the company that is maintained through increased equity based on retained earnings. Thus the company only issues enough debt to maintain a constant debt to equity ratio. The sustainable growth rate is a measurement of the maximum level of sales growth that a company can achieve without issuing new shares or changing its operating and financing policies [17]. 


\section{Environmental Performance and Sustainable Financial Development}

The criteria for evaluating environmental performance can be measured through PROPER which ranks environmental performance based on 5 ratings namely gold, green, blue, red, and black. PROPER measurement indicators consist of two categories, namely obedience assessment criteria and assessment criteria more than those required in regulations. The criteria for evaluating obedience in answering questions in case the company complies with environmental management regulations. The criteria for evaluating more than those required in regulations are more dynamic because they are adapted to technological developments, the application of best environmental management practices and global environmental issues [7].

Investment incurred by companies in carrying out environmental protection will increase company spending in the short term. Environmental performance in its improvement requires increased funds to manage resources that can support environmental protection during the year. However, the capacity of funds and resources is a limitation that must be cultivated by every company. Increased investment in environmental protection will indirectly reduce investment in normal production management, so reducing this input will reduce financial performance in the short term but will increase the company's competitive advantage in the long run [10].

$\mathrm{Ha}_{1}$ : Environmental performance affect sustainable financial development

\section{E. Financing Decisions and Sustainable Financial Development}

Companies in financing according to trade-off theory can be financed through internal and external financing. Internal financing comes from obligations to third parties and external financing comes from company equity. Companies usually execute financing decisions based on a combination or mix of debt and equity that the company uses to finance its long-term operations. If the company uses external financing, the company must incur certain costs associated with this financing decision $[11,13]$. There are two types of factors that influence the financing decisions of each company, namely internal and external factors. Internal factors that influence the company's financing decisions include the financing period and objectives, business size, nature of the business, regularity and certainty of income, and asset structure. External factors that influence corporate financing decisions include financial organization policies, funding costs, seasonal variations, economic fluctuations, the nature of competition, and capital market conditions. The optimal and best funding structure in combining debt and equity is expected to maximize company performance and minimize the cost of capital [11].

Pecking order theory illustrates that companies prefer to use internal financing because the cost of funding from internal sources is smaller than the cost of debt and equity through external funding. Higher debt levels limit new financing opportunities and worsen the company's financial performance through charging interest costs that must be paid by the company. Although higher debt levels in a company's capital structure can increase firm value in the short run, in the long run it can produce a greater negative financial impact and can increase potential liquidity costs which can increase liquidity risk [10].

$\mathrm{Ha}_{2}$ : External financing decisions through short-term debt affect sustainable financial development

The problem of information asymmetry slightly affects the company's choice in determining the maturity of the debt. The main factors that cause these problems are the probability of bankruptcy and the suitability of debt maturity [18]. Companies that are committed to environmental protection and are industries that have high growth have the highest likelihood of survival through adequate financing to support sustainable performance improvement [19]. Long-term debt can increase the return on profits from returns below normal because the company can enjoy the tax benefits of charging interest costs that arise from the use of long-term debt.

$\mathrm{Ha}_{3}$ : External financing decisions through long-term debt affect sustainable financial development

The company increases environmental exposure to improve environmental performance and production efficiency through technological innovation. If income is not enough to cover investment costs, it will have a negative impact on the value of the company and the interests of shareholders. The environmental protection behavior that the company seeks can send good signals to investors, thereby reducing costs incurred from external financing. Excessive environmental investment will take internal funds and offset the benefits of internal financing [18].

$\mathrm{Ha}_{4}$ : Internal financing decisions affect sustainable financial development

\section{RESEARCH METHODOLOGY}

This research is a quantitative research that aims to examine the relationship between environmental performance and financing decisions on sustainable financial development that is controlled by growth opportunities. The data collection method in this research is documentation by collecting the necessary data derived from books and articles from media that have a relationship with the same problem in research discussions and various sources of data publication such as company and IDX websites. Data sources of this research are dividends paid, net income, sales, total equity, total liabilities, total short-term liabilities, and total long-term liabilities derived from secondary data obtained from financial statements and PROPER ratings sourced from the company's annual report. The data research is analyzed using multiple regression analysis.

The population of this research are all companies listed on the Indonesia Stock Exchange. The research sample was all mining companies listed on the Indonesia Stock Exchange in a row from 2015-2018. The research sample selection method used in this research uses purposive sampling, which is a nonrandom sample selection method with the aim of obtaining a representative sample according to specified criteria. The selection criteria for this research sample are (1) Mining companies listed on the Indonesia Stock Exchange successively from 2015-2018; (2) Have annual reports and financial statements publications at the end of the 31 December fiscal year in a row from 2015-2018; (3) Participated in PROPER in a row from 2015-2018; and (4) Had positive retained earnings in a row from 2015-2018. 
The dependent variable in this research is sustainable financial development measured using the Sustainable Growth Rate (SGR) [20]. Sustainable Growth Rate (SGR) is the maximum rate of growth in sales a company can achieve without issuing new shares or changing in its financing policy which results its debt-to-equity ratio and dividend payout ratio remain the same [17]. The sustainable development of the company depends on two factors which were the retention rate by dividend payout ratio and financial performance of the equity by return on equity. The greater return of the equity the greater the rate of growth and vice versa. The higher the dividend payout ratio, the lower the rate of growth of the company. Sustainable Growth Rate (SGR) can be counted in formula as follows.

\section{SGR = (1 - Dividend Payout Ratio $) \times$ Return On Equity}

[Dividend Payout Ratio = Dividend paid / net income; Return on Equity $=$ Net income $/$ total equity]

The independent variables in this research are environmental performance and financing decisions. Environmental performance measured by ratings result from PROPER which divided the rating into 5 colors with the following definitions:

- Gold, given to the person in charge of business and/or activities that have consistently demonstrated environmental excellence in the production process and/or services, implementing ethical business and responsible to the community;

- Green, is given to the person in charge of operations and/or activities that have environmental management more than required under the rules (beyond compliance) through the implementation of environmental management system, efficient resource use through efforts 4R (Reduce, Reuse, Recycle and Recovery), and make efforts to social responsibility (CSR/Community Development) well;

- Blue, awarded to the person in charge of operations and/or activities that have made the effort on environmental management in accordance with the rules and/or regulations;

- Red, is given to the person in charge of operations and/or activities of environmental management which efforts do not comply with the requirements stipulated in the legislation; and

- Black, given to the person in charge of business and/or activities that intentionally perform any act or omission that resulted in contamination and/or damage to the environment as well as violations of the laws or not imposing administrative sanctions.

In this research, PROPER ranking in measuring environmental performance is measured by a nominal scale where the PROPER rating is given a score with the following category indicators such as: (1) Gold (very good); score $=5$; (2) Green (very good); score = 4; (3) Blue (good); score = 3; (4) Red (not good); score $=2$; and (5) Black (not good); score $=1[21]$.

The financing decisions in this research are divided into total financing decisions, internal financing decisions and external financing decisions which the measurement referred to
[21]. Financing decisions were measured using the short-term debt ratio (STD), long-term debt ratio (LTD), and Retained Earnings Ratio. Short term debt to asset ratio and long term debt ratio were used to measure external financing decisions of the company for short term and long term specific period [11]. To assess the level of internal financing, we used the retained earnings ratio to reflect the firm's use of profits compared to the use of external sources to fund projects [22]. Retained earnings ratio can be calculated as follows.

Retained Earnings Ratio $=$ (Retained Earnings + Provisions)/Total Assets

Growth opportunities are used as control variables that control the effect of financial performance and financing decisions on sustainable financial development. Growth opportunities based on the level of company sales growth from year to year [10]. Growth opportunities can be calculated using the following formula.

Growth Opportunities $=($ Sales in the year end period Sales in the beginning of year period) / Sales in the beginning of year period

\section{RESULTS AND DISCUSSION}

Mining companies listed on the Indonesia Stock Exchange consistently from 2015-2018 totaled 39 companies. During the observation period, there were 5 companies that did not publish annual reports and financial reports consistently from 2015 2018. In addition, there were 19 companies that did not consistently participate in PROPER from 2015-2018 and there were 6 companies that had negative retained earnings in a row from 2015-2018. Based on this, only 10 mining companies can be selected from 39 manufacturing companies listed on the Indonesia Stock Exchange from 2015-2018 to become a research sample so that the overall data amounted to 40 .

The descriptive statistics that used in this research such as means, maximum, and minimum. Environmental performance has a minimum value of 2 with a red rating and a maximum value of 4 with a green rating. The average value of environmental performance is 3 with a blue rating and standard deviation of 0.1388 . This shows that the average environmental performance of mining companies listed on the Indonesia Stock Exchange is still relatively adequate. External financing decisions have a minimum value of 0.1084 and a maximum value of 4.4476 . The average value of external financing decisions is 0.9922 and the standard deviation is 1.0265 . This means that mining companies listed on the Indonesia Stock Exchange prefer debt-based funding compared to equity.

External financing decisions through short-term debt have a minimum value of 0.0592 and a maximum value of 0.4085 . The average value of external financing decisions through short-term debt is 0.1954 and the standard deviation is 0.0897 . This shows that the average external financing decision through short-term debt to mining companies listed on the Indonesia Stock Exchange is still relatively low. External financing decisions through long-term debt have a minimum value of 0.0121 and a maximum value of 0.6652 . The average value of external financing decisions through long-term debt is 0.2151 and the standard deviation is 0.1797 . This shows that the average external financing decision through long-term debt to mining companies listed on the Indonesia Stock Exchange is still relatively low. 
Internal financing decisions have a minimum value of 0.0000 and a maximum value of 0.7211 . The average value of internal financing decisions is 0.3810 and the standard deviation is 0.1959. This shows that the average internal financing decision through equity in mining companies listed on the Indonesia Stock Exchange is still relatively low because the mining companies listed on the Indonesia Stock Exchange prefer funding through debt rather than equity. Growth opportunities have a minimum value of 0.0000 and a maximum value of 0.9948 . The average value of growth opportunities is 0.1863 and the standard deviation is 0.2466 . This shows that the average growth opportunity in mining companies listed on the Indonesia Stock Exchange is relatively high because it has moderate average sales growth annually with volatile commodity price movements.

The results of the normality test show that the residual data are normally distributed, so it can be concluded that the research data meets the normality assumption and is suitable to be used in this research. Multicollinearity test results show that environmental performance, external financing decisions through short-term debt, external financing decisions through long-term debt, internal financing decisions, and growth opportunities have tolerance values above 0.1 and VIF values below 10 that means the regression model is free from multicollinearity problems. Heteroscedasticity test results show that there is no heteroscedasticity on environmental performance, external financing decisions through short-term debt, external financing decisions through long-term debt, internal financing decisions, and growth opportunities. The autocorrelation test results show that the residuals data of environmental performance, external financing decisions through short-term debt, external financing decisions through long-term debt, internal financing decisions, and growth opportunities are free from autocorrelation problems and can be used in research.

Correlation test results show a positive $R$ value of 1 . $R$ value obtained is 0.713 which is greater than 0.5 which indicates that there is a strong relationship between environmental performance, external financing decisions through short-term debt, external financing decisions through long-term debt, internal financing decisions, and growth opportunities with sustainable finance development. The adjusted R-square value of 0.418 shows $41.8 \%$ of the variation of sustainable finance development can be explained by environmental performance, external financing decisions through short-term debt, external financing decisions through long-term debt, internal financing decisions, and growth opportunities. The remaining $58.2 \%$ is explained by other factors outside the regression model.

\section{TABLE I. RESEARCH OUTPUT}

\begin{tabular}{|l|l|c|}
\hline \multicolumn{1}{|c|}{ Variable } & Coefficient & Sig. \\
\hline Constant & $-0,499$ & \\
\hline Environmental performance & 0,412 & 0,049 \\
\hline $\begin{array}{l}\text { External financing decisions through } \\
\text { short-term debt }\end{array}$ & 0,525 & 0,131 \\
\hline $\begin{array}{l}\text { External financing decisions through long- } \\
\text { term debt }\end{array}$ & 0,273 & 0,475 \\
\hline Internal financing decisions & $-0,086$ & 0,618 \\
\hline Growth Opportunities & 0,311 & 0,003 \\
\hline
\end{tabular}

Based on table 1, the regression model can be formulated as follows.
$\mathrm{SGR}_{\mathrm{i}, \mathrm{t}}=-0.499+0.412$ PROPER $-0.114 \mathrm{TDR}+0.525$ $\mathrm{SDR}+0.273 \mathrm{LDR}-0.086 \mathrm{RET}+0.311 \mathrm{GO}+\mathrm{e}_{\mathrm{i}, \mathrm{t}}$

Environmental performance has a beta value of 0.412 and sig. amounted of 0.049 . This shows that $\mathrm{Ha}_{1}$ is accepted which means that environmental performance has a positive effect on sustainable finance development. The results of this research are consistent with other research [1,7-10]. Increases in costs related to environmental protection can indirectly have an impact on reducing investment in normal production management. Reducing these inputs, although reducing financial performance in the current year in the short term, will increase the company's competitive advantage in the long run. These results also support the theory of legitimacy which states companies can get legitimacy from the public in carrying out environmental protection activities.

External financing decisions through short-term debt have a beta value of 0.525 and sig. amounted to 0.131 . This shows that $\mathrm{Ha}_{2}$ is rejected, which means that external financing decisions through short-term debt have no effect and have a positive relationship to sustainable finance development. The results of this research are consistent with research by Dand et al.; and Khan et al. [5,11], but not consistent with research by Zhang and Chen; and Admasu [10,12]. Companies with high profit levels tend to face higher costs in funding external financing. Companies that depend on short-term debt can be affected by interest rate volatility which imposes high interest costs. Shortterm debt usually requires a longer period to realize the optimal rate of return. However, mining companies in Indonesia do not pay attention to the composition of the size of short-term debt because the portion of short-term debt taken by mining companies is not as long as long-term debt and short-term debt is intended for working capital needs of the company with interest expense paid repeatedly every month depending on its use so it does not have a big impact on the company's financial performance in the long run.

External financing decisions through long-term debt have a beta value of 0.273 and sig. amounted to 0.475 . This shows that $\mathrm{Ha}_{3}$ is rejected, which means that external financing decisions through long-term debt have no effect and have a positive relationship to sustainable finance development. The results of this research are consistent with research by Dand et al.; and Khan et al. [5,11], but not consistent with research by Zhang and Chen; and Admasu [10,12]. Transaction costs arising from long-term debt tend to be greater than the cost of funds in the use of short-term debt and equity. This is due to the high investment costs incurred by coal companies that require significant long-term financing to maintain operating cash flow so that the continuity of operations continues so that it does not have a major impact on the company's financial performance in the long run.

Internal financing decisions have a beta value of -0.086 and sig. amounted to 0.618. This shows that $\mathrm{Ha}_{4}$ was rejected, which means that external financing decisions through longterm debt have no effect and have a negative relationship to sustainable finance development. The results of this research are not consistent with [10]. This research result does not support pecking theory that debt is more preferable to be chosen as internal financing resources. Internal funding structures do not incur interest costs that companies incur from loans they obtain. But based on the theory of pecking orders the company prefers external funding due to the risk associated 
with lower internal financing. Coal companies that need to incur large investment and environmental protection costs tend to rely more on bank loans than funding through equity by issuing shares in the capital market that do not have a large impact on the company's financial performance in the long run.

\section{CONCLUSIONS AND SugGESTIONS}

Environmental performance has a beta value of 0.412 and sig. of 0.049 . This shows that $\mathrm{Ha}_{1}$ is accepted which means that environmental performance has a positive effect on sustainable finance development. These results support the research of others [1,7-10]. External financing decisions through shortterm debt have a beta value of 0.525 and sig. amounted to 0.131. This shows that $\mathrm{Ha}_{2}$ is rejected, which means that external financing decisions through short-term debt have no effect and have a positive relationship to sustainable finance development. These results of this research are consistent with research by Dand et al.; and Khan et al. [5,11], and inconsistent with research by Zhang and Chen; and Admasu [10,12].

External financing decisions through long-term debt have a beta value of 0.273 and sig. amounted to 0.475 . This shows that $\mathrm{Ha}_{3}$ is rejected, which means that external financing decisions through long-term debt have no effect and have a positive relationship to sustainable finance development. These results of this research are consistent with research by Dand et al.; and Khan et al. [5,11], and inconsistent with research by Zhang and Chen; and Admasu [10,12]. The internal financing decision has a beta value of -0.086 and a value of sig. amounted to 0.618 . This shows that $\mathrm{Ha}_{4}$ was rejected, which means that external financing decisions through long-term debt have no effect and have a negative relationship to sustainable finance development. These results of this research are not consistent with [10].

The suggestion for next research are to add others variables that affect sustainable financial development such as media exposure and environmental initiatives and replace research samples object with manufacturing companies because the manufacturing industry sector is the commonly industry that easily highlighted by the public.

The implications that can be given to companies from the results of this research can be a reference for companies, especially the mining sector, to be able to support policies that affect the environment and financing policies that are in accordance with the needs and achievement of corporate strategies in supporting sustainable development.

The implications that can be given for the government from the results of this research are the research can be a reference for the government to continue encourage the companies to carry out operational responsibility for the surrounding environment through their participation in PROPER and grow companies financing externally in the form of sustainable bonds as one of the government's efforts to commit to realize SDGs in supporting sustainable development.

For investors, the results of this research can be a reference for investors in making investment decisions in terms of the company's efforts to be responsible for the surrounding environment through participation in the PROPER award and the company's commitment to get external funding through sustainable bonds with the company's commitment to the environment to help increase returns capital that is adjusted to the risk of the company in creating economic value, especially shareholder value. For subsequent research, the results of this research can be used as a reference for subsequent research to develop broader topics that can highlight other sustainability issues faced by companies that have an operational impact on the environment.

\section{REFERENCES}

[1] M. Munawaroh, I. Ghozali, F. Fuad, and F. Faisal, "The Trade Off Strategy Between Financial and Environmental Performance: Assessment of Sustainable Value Added," International Journal of Energy Economics and Policy, vol. 8, no. 1, pp. 5-11, 2018.

[2] N. Kuosmanen and T. Kuosmanen, "Consistent Aggregation of Generalized Sustainable Values from The Firm Level to Sectoral, Regional or Industry Levels," Sustainability, vol. 5, pp. 1568-1576, 2013.

[3] F. Figge and T. Hahn, "Value Drivers of Corporate Eco-efficiency: Management Accounting Information for The Efficient Use of Environmental Resources," Management Accounting Research, vol. 24, no. 4, pp. 387-400, 2013.

[4] F. Figge and T. Hahn, "Is Green and Profitable Sustainable? Assessing the Trade-off Between Economic and Environmental Aspects Environmental Performance," International Journal of Production, vol. 140, no. 1, pp. 92-102, 2012.

[5] W.M.N.W. Daud, N.M. Norwani, A.A. Mansor, and W.A. Endut, "Does Financing Decision Influence Corporate Performance in Malaysia," International Journal of Economic and Financial Issues, vol. 6, no. 3, pp. 1165-1171, 2016.

[6] J. Abor, "The Effect of Capital Structure on Profitability: An Empirical Analysis of Listed Firms in Ghana," The Journal of Risk Finance, vol. 65 , no. 5, pp. 438-445, 2005 .

[7] D. Angelia and R. Suryaningsih, "The Effect of Environmental Performance and Corporate Social Responsibility Disclosure Towards Financial Performance (Case Research to Manufacture, Infrastructure, and Service Companies That Listed at Indonesia Stock Exchange)," Procedia - Social and Behavioral Sciences, vol. 211, pp. 348-355, 2015.

[8] S. Manrique and C.P.M. Ballester, "Analyzing The Effect of Corporate Environmental Performance on Corporate Financial Performance in Developed and Developing Countries," Sustainability, vol. 9, pp. 19-57, 2017.

[9] V.B. Sanchez and A.S. Carlos, "Environmental Proactivity and Environmental and Economic Performance: Evidence from The Winery Sector," Sustainability, vol. 8, pp. 1-15, 2016.

[10] K.Q. Zhang and H.H. Chen, "Environmental Performance and Financing Decisions Impact on Sustainable Financial Development of Chinese Environmental Protection Enterprises," Sustainability, vol. 9, pp. 1-14, 2017.

[11] A. Khan, M. Saikh, A.B. Shah, and I. Zahid, and F.M. Shaikh, "Impact on Financing Decisions on Firm's Performance: An Empiritical Research of Pakistan Listed Firm's in KSE," International Journal of Management and Information Technology, vol. 12, no. 1, pp. 30503056, 2017.

[12] N.A. Admasu, "The Impact of Capital Structure Choice on Firms' Financial Performance: Evidence from Manufacturing PLCs in Tigrai Region, Ethiopia," Journal of Poverty, Investment, and Development, vol. 27, pp. 5-11, 2016.

[13] S.C. Myers, “The Capital Structure Puzzle,” Journal of Finance, vol. 39, pp. 575-592, 1984.

[14] C. Deegan, M. Rankin, and J. Tobin, "An Examination of the Corporate Social and Environmental Disclosures of BHP from 1983-1997: A Test of Legitimacy Theory," Accounting, Auditing \& Accountability Journal, vol. 15 , no. 3, pp. 312-343, 2002.

[15] J. Dowling and J. Pfeffer, "Organizational legitimacy: Social values and organizational behaviour," Pacific Social Review, vol. 18, no. 1, pp. 122-136, 1975.

[16] F. Figge and T. Hahn, "Sustainable Value Added-Measuring Corporate Contributions to Sustainability Beyond Eco-efficiency," Ecological Economics, vol. 48, pp. 173-187, 2004. 
[17] G. Hawawini and C. Viallet Finance for Executive. Managing for Value Creation. South-Western Cengage Learning, 2007, p. 163.

[18] F.C. Scherr and H.M. Hulburt, "The Debt Maturity Structure of Small Firms,” Financ. Manag, vol. 30, pp. 85-111, 2001.

[19] D. Audretsch and M. Keilbach, "Entrepreneurship Capital and Economic Performance," Reg. Stud, vol. 38, pp. 949-959, 2004.

[20] A. Kijewska, "Condition for Sustainable Grwoth (SGR) for Companies from Metallurgy and Mining Sector in Poland,” Metalurgija, vol. 55, no. 1, pp. 139-142, 2017.
[21] N.M. Machdar, "Corporate Financial Performance, Corporate Environmental Performance, Corporate Social Performance, and Stock Return," JMK, vol. 19, no. 2, pp. 118-124, 2017.

[22] A.E.M. Twairesh, "The Impact of Capital Structure on Firm's Performance Evidence from Saudi Arabia," J. Appl. Financ. Bank, vol. 4, pp. 183-193, 2014. 